Eur. J. Clin. Chem. Clin. Biochem.

Vol. 32, 1994, pp. 709-717

(c) 1994 Walter de Gruyter \& Co.

Berlin. New York

\title{
A Manual Spectrophotometric Method for the Measurement of Serum Sodium and Potassium by Enzyme Activation
}

\author{
By R. D. Mazzachi, B. C. Mazzachi and M. N. Berry
}

Department of Biochemistry and Chemical Pathology, Flinders Medical Centre, Bedford Park, South Australia, Australia

(Received March 21/July 7, 1994)

Summary: Manual procedures suitable for use on standard benchtop spectrophotometers have been developed for the enzymatic determination of $\mathrm{Na}^{+}$and $\mathrm{K}^{+}$in serum. Both assays require only minimal modification of reagents already available for $\mathrm{BM} / \mathrm{Hitachi}$ analyzers and are performed in an endpoint mode, allowing up to 20 assays per run. The addition of a stop reagent is required - dipotassium EDTA for the $\mathrm{Na}^{+}$assay and sodium dodecyl sulphate for the $\mathrm{K}^{+}$assay. The most important criterion for achieving good assay performance is the precise pipetting of sample and reagent. Within-run imprecision is $<1 \%$ for $\mathrm{Na}^{+}$and $\mathrm{K}^{+}$, and between-run imprecision $<1.5 \%$, for both assays at all but the lowest concentrations of $\mathrm{K}^{+}$. Enzymatic electrolyte results compare well with flame photometry, however the assays are more prone to interference by very high concentrations of bilirubin or triacylglycerols than those performed on automated, dual-wavelength kinetic analyzers. It is possible to correct for most interferences by inclusion of appropriate sample and reagent blanks.

\section{Introduction}

We have previously published methods for the enzymatic determination of $\mathrm{Na}^{+}$and $\mathrm{K}^{+}$in sera $(1,2)$. The $\mathrm{Na}^{+}$assay involves the activation by $\mathrm{Na}^{+}$of $\beta$-galactosidase $^{1}$ ) which catalyses the conversion of $o$-nitrophenyl$\beta$ - $D$-galactopyranoside to galactose and $o$-nitrophenol, a reaction that can be monitored at $405 \mathrm{~nm}(1)$. For $\mathrm{K}^{+}$ determination pyruvate kinase is activated by $\mathrm{K}^{+}$leading to the conversion of phosphoenolpyruvate to pyruvate which in turn is reduced to lactate by lactate dehydrogenase with concomitant oxidation of NADH. The resultant absorbance decrease is monitored at $340 \mathrm{~nm}$ (2). Reagents for these analyses have become available in kit form for use in medium to high throughput biochemical analysers such as the BM/Hitachi 717. There

\footnotetext{
1) Enzymes:

$\beta$-galactosidase:

$\beta-D$-Galactoside galactohydrolase EC 3.2.1.23

Glutamate dehydrogenase: $L$-Giutamate : NAD(P) oxidoreductase EC 1.4.1.3

$D$-Lactate dehydrogenase:

Pyruvate kinase:

[D]-Lactate : NAD oxidoreductase EC 1.1.1.28

ATP : pyruvate phosphotransferase EC 2.7.1.40
}

are considerable demands for the analysis of $\mathrm{Na}^{+}$and $\mathrm{K}^{+}$in smaller biochemistry diagnostic laboratories where highly mechanized analysers are not available. In these circumstances manual procedures which can take advantage of the availability of the enzymatic kit reagents while making use of basic benchtop spectrophotometers are desirable.

The most convenient way to perform a linear kinetic assay manually is to measure the change in absorbance between two time points. For both assays, an initial reading can be taken prior to starting the enzymatic reaction by addition of a start reagent, and a second reading made following the addition of a stop reagent. Taking this into account we here describe modifications of the previously published enzymatic $\mathrm{Na}^{+}$and $\mathrm{K}^{+}$assays $(1,2)$ that allow their determination by manual procedures using a benchtop spectrophotometer. We have endeavoured to utilise the existing kit reagents with minimal modification.

\section{Materials and Methods}

Instrumentation

A Shimadzu UV-160 Recording Spectrophotometer (Shimadzu Corporation, Kyoto, Japan) linked to a Tempette Junior TE-8J 
(Techne Inc., Princeton, NJ, U.S.A.) recirculating water bath heater was used for all absorbance measurements at $37^{\circ} \mathrm{C}$. To economise by means of reduced reagent volumes, we used quartz cuvettes of $4 \mathrm{~mm}$ internal width $\times 10 \mathrm{~mm}$ path length with a total volume of $1.5 \mathrm{ml}$. On this particular spectrophotometer black metal masks were required on the cell holders to reduce stray light. When these masks were not employed the linear working range of absorbance readings on the spectrophotometer was significantly reduced when compared to conventional $10 \mathrm{~mm} \times 10 \mathrm{~mm}$ cuvettes. Routine emission flame photometry (IL943, Instrumentation Laboratory Inc., Lexington, MA, U.S. A.) was used for comparison of all electrolyte results.

\section{Other equipment}

The main $(\mathrm{R} 1)$ reagents $(1 \mathrm{ml})$ were pipetted with an Eppendorf Multipette 4780 (Eppendorf Gerätebau Netheler + Hinz GmbH, Hamburg, Germany) fitted with a $12.5 \mathrm{ml}$ capacity combitip. Standards and samples were added by means of an SMI 1075C Micro/ pettor (Scientific Manufacturing Industries, Berkeley, CA, U.S. A.). Start (R2) reagents were added with Eppendorf 4710 Varipettes of $10-100 \mu \mathrm{l}$ capacity. Stop reagents were added using the Multipette 4780 with a $5 \mathrm{ml}$ capacity combitip for $\mathrm{Na}^{+}$and a 2.5 $\mathrm{ml}$ combitip for $\mathrm{K}^{+}$.

\section{Calibrators}

Both $\mathrm{Na}^{+}$and $\mathrm{K}^{+}$assays were calibrated with ISE low $\left(\mathrm{Na}^{+}: 120\right.$ $\left.\mathrm{mmol} / \mathrm{l}, \mathrm{K}^{+}: 3 \mathrm{mmol} / \mathrm{l}\right)$ and ISE high $\left(\mathrm{Na}^{+}: 160 \mathrm{mmol} / \mathrm{l}, \mathrm{K}^{+}\right.$: $7 \mathrm{mmol} / \mathrm{l}$ ) standards (Boehringer Mannheim Cat. No. 1183974 and 1183982). The flame photometer was calibrated with a $1: 1 \mathrm{mix}$ ture of the ISE low and high standards.

\section{Samples}

Specimens anticoagulated with lithium heparin were used for all patient comparisons. Sera pools were used for all precision, linearity and interference studies.

In order to assess any bias in the enzymatic assays three human serum based reference materials (SRM 909, 909a-1 and 909a-2), were obtained from the National Institute of Science and Technology (NIST), Gaithersburg, MD 20899, U.S.A. The NIST assigned concentrations of sodium and potassium in these samples are determined by definitive methods (gravimetry with ion-exchange separation and flame emission spectroscopy for $\mathrm{Na}^{+}$and isotope dilution mass spectrometry and inductively coupled plasma spectrometry for $\mathrm{K}^{+}$).

\section{Reagents}

The basic formulations of the $\mathrm{Na}^{+}$and $\mathrm{K}^{+}$enzymatic reagents are shown in table 1 and are similar to those previously published (1, 2 ). For the manual assays we have adapted the commercially available products $\mathrm{Na}^{+}$SYS1 BM/Hitachi 704/717, \#1298054 and $\mathrm{K}^{+}$ SYS1 BM/Hitachi 704/717, \#1298011. In order to accommodate the relatively larger volumes required both for manual pipetting and absorbance measurements, the main reagents were reconstituted with extra water. To maintain concentration parity with the kinetic procedures, the $R 2$ lyophilisates were therefore reconstituted with reduced diluent volumes (tab. 1). All reconstituted reagents were stable for at least one week at $4^{\circ} \mathrm{C}$.

Tween 80 (polyoxyethylene sorbitan mono-oleate) and ethylenediamine-tetraacetic acid (EDTA, dipotassium salt) were obtained from Sigma, Sydney, Australia. Sodium dodecyl sulphate (SDS)。 was supplied by Boehringer Mannheim Pty. Ltd., Sydney, Australia.
Tab. 1 Reconstitution of the $\mathrm{BM} \mathrm{Na}^{+}$and $\mathrm{K}^{+}$reagent lyophilisates and the active reagent components of the manual enzymatic assays.

$\mathrm{Na}^{+} \mathrm{Rl}$

Buffer 1 (45 ml, normal reconstitution volume) $+24 \mathrm{ml}$ water $+350 \mu \mathrm{l}$ Tween 80

$\mathrm{Na}^{+} \mathrm{R} 2$

Diluent 2 ( $8 \mathrm{ml}$, reduced reconstitution volume)

$\mathrm{Na}^{+}$reagent components

Tris (hydroxymethyl) aminomethane hydrochloride buffer $\mathrm{pH} 9.0$ Magnesium sulphate

Lithium chloride

4,7,13,16,21-Pentaoxa 1,10-diazabicyclo[8.8.5]tricosane (Kryptofix 221)

Ethylenebis(oxyethylenenitrilo) tetraacetic acid [EGTA]

$\beta$-Galactosidase

2-Nitrophenyl- $\beta-D$-galactopyranoside

Serum albumin

$\mathrm{Na}^{+}$stop reagent

Dipotassium ethylenedinitrilo tetraacetic acid [EDTA], $0.75 \mathrm{~mol} / \mathrm{l}$, adjusted to $\mathrm{pH} 7.0$ with potassium hydroxide (about $28 \mathrm{~g} / \mathrm{l}$ is required)

$\mathrm{K}^{+} \mathrm{Rl}$

Buffer 1 (50 ml, normal reconstitution volume) $+17 \mathrm{ml}$ water $+350 \mu$ l Tween 80

$\mathrm{K}^{+} \mathrm{R} 2$

Diluent 2 ( $7 \mathrm{ml}$, reduced reconstitution volume)

$\mathrm{K}^{+}$reagent components

Tris (hydroxymethyl) aminoethane hydrochloride buffer $\mathrm{pH} 8.15$

4,7,13,16,21-Pentaoxa 1,10-diazabicyclo[8.8.5]tricosane (Kryptofix 221)

Adenosine-5'-diphosphate

$\beta$-Nicotinamide-adenine dinucelotide, reduced $(\mathrm{NADH})$

Lithium chloride

Manganese chloride

2-Oxoglutarate

Glutamate dehydrogenase

Pyruvate kinase

Phosphoenolpyruvate, tricyclohexylammonium salt

Lactate dehydrogenase

Serum albumin

$\mathrm{K}^{+}$stop reagent

Sodium dodecyl sulphate, $170 \mathrm{~g} / \mathrm{l}$ (may require heat with stirring to dissolve)

\section{Statistical methods}

The Passing-Bablok regression test (3) was applied to the patient comparison data with the program in a MS-DOS format kindly supplied by Dr. W. Bablok (Department of Evaluation and Biometry, Boehringer Mannheim $\mathrm{GmbH}$, Germany). $S_{y \cdot x}$ data from the Standardized Principal Component analysis procedure and coefficient of correlation values were also calculated from this program.

\section{$\mathrm{Na}^{+}$assay}

Use the Eppendorf multipette on number 4 setting, $12.5 \mathrm{ml}$ capacity combitip. Pipette $1.0 \mathrm{ml}$ of $\mathrm{Na}^{+} \mathrm{Rl}$ and mix with $25 \mu \mathrm{l}$ of sample (run singly) or standard (run in duplicate; one at the beginning and one at the end of the rurt) in a $3 \mathrm{ml}$ tube and equilibrate 
for at least 5 minutes in a $37^{\circ} \mathrm{C}$ water bath. Transfer the mixture to a microcuvette for an initial absorbance reading at a wavelength of $405 \mathrm{~nm}\left(\mathrm{~A}_{\mathrm{i}}\right)$ and return it to the $3 \mathrm{ml}$ tube. Take initial readings for all samples before starting the reaction in each tube by adding sequentially $50 \mu$ l of the concentrated $\mathrm{Na}^{+} \mathrm{R} 2$ (prewarmed at $37^{\circ} \mathrm{C}$ for 5 minutes) to each tube. An interval of $20 \mathrm{~s}$ provides adequate time for addition and mixing of the $\mathrm{R} 2$ reagent to each tube. After incubating the tubes for exactly $8 \mathrm{~min}$ add $200 \mu \mathrm{l}$ dipotassium EDTA solution and mix thoroughly, then take another absorbance reading. This final absorbance $\left(A_{f}\right)$ remains unchanged at room temperature for at least $15 \mathrm{~min}$.

In order to calculate results, it is necessary to correct the $A_{f}$ of calibrators and unknown samples for the dilution of the reagent mixture brought about by the addition of $\mathrm{R} 2$ and the stop reagent. This correction $\left(A_{c}\right)$ is particularly important when there is a spurious absorbance caused by a component not present in aqueous standards (e.g. triacylglycerols) that may vary significantly between serum samples. The concentration of $\mathrm{Na}^{+}$in a sample is then calculated from the difference in absorbance between $A_{i}$ and $A_{c}$ for that sample, and then determined from a standard linear equation derived from the low $\mathrm{Na}^{+}$and high $\mathrm{Na}^{+}$calibrators. The calculation of these results is shown together with worked examples in the Appendix.

\section{$K^{+}$assay}

The procedure for performing and calculating the results of an enzymatic $\mathrm{K}^{+}$assay is similar to that for $\mathrm{Na}^{+}$assay with the following exceptions.

Prewarm $20 \mu \mathrm{l}$ sample and $1.0 \mathrm{ml}$ main reagent for 10 minutes to allow the removal of endogenous $\mathrm{NH}_{4}^{+}$in sera. Due to the high initial absorbance of NADH at $340 \mathrm{~nm}$ which is above the spectral linearity of standard benchtop spectrophotometers, readings are taken at $360 \mathrm{~nm}$ wavelength where the extinction coefficient of $\mathrm{NADH}$ is approximately $50 \%$ of that at $340 \mathrm{~nm}$. Stop the reaction by the addition of $250 \mu \mathrm{l}$ of a $170 \mathrm{~g} / 1$ dodecyl sulphate solution. The changes in absorbance values are determined as described above for $\mathrm{Na}^{+}$. Likewise the concentration of $\mathrm{K}^{+}$in a sample can be calculated from the absorbance values of the sample and the 3.00 and $7.00 \mathrm{mmol} / 1 \mathrm{~K}$ calibrators (see Appendix).

\section{Accuracy}

The three SRM materials were assayed according to NCCLS EP10-T criteria (4). In this procedure each material is assayed 3 times per run in a strict order sequence. One run is performed each day for 5 days.

\section{Interference}

Studies demonstrating the effect of haemoglobin, bilirubin and lipaemia on the assays were based on the procedure of Glick et al. (5). In order to keep the actual concentrations of $\mathrm{Na}^{+}$and $\mathrm{K}^{+}$ constant, two separate portions of a serum pool were treated with a similar volume of water or interfering substance. Solutions with intermediate concentrations between these low and high pools were then prepared as required.

A group of 47 of the most commonly prescribed drugs in our hospital were tested for interference in the enzymatic $\mathrm{Na}^{+}$and $\mathrm{K}^{+}$ assays by adding them to samples from a serum pool at levels usually 5 times the upper normal expected therapeutic level, based on NCCLS EP7-P guidelines (6).

\section{Results}

A condition essential for the satisfactory performance of both assays is precise pipetting, particularly of the sam- ple and main (R1) reagent. The multipette is very suitable for pipetting $\mathrm{R} 1$ reagent as, on a number 4 setting and $12.5 \mathrm{ml}$ capacity combitip, it is routinely capable of delivering $1 \mathrm{ml}$ of water with a $\mathrm{CV}$ of $<0.15 \%$, as determined by weighing on an analytical balance. However pipetting precisions do vary depending on combitip size and setting number. Likewise, a $25 \mu l$ sample can be pipetted with a $\mathrm{CV}<0.30 \%$ with the SMI micro/pettor.

\section{Absorbance characteristics}

After correction, typical absorbance changes are 1.30 $\Delta \mathrm{A}$ for the $120 \mathrm{mmol} / 1 \mathrm{Na}^{+}$and $1.65 \Delta \mathrm{A}$ for the 160 $\mathrm{mmol} / 1 \mathrm{Na}^{+}$calibrators. This is equivalent to an absorbance change of almost $0.01 \Delta \mathrm{A}$ per mmol/l $\mathrm{Na}^{+}$over the $8 \mathrm{~min}$ measuring interval. In the $\mathrm{K}^{+}$assay an absorbance change of $-0.45 \Delta \mathrm{A}$ and $-0.85 \Delta \mathrm{A}$ can be expected for the $3.00 \mathrm{mmol} / 1 \mathrm{~K}^{+}$and $7.00 \mathrm{mmol} / \mathrm{l} \mathrm{K} \mathrm{K}^{+}$ calibrators respectively, i. e. $-0.01 \Delta \mathrm{A}$ per $0.1 \mathrm{mmol} / \mathrm{l}$ $\mathrm{K}^{+}$per $8 \mathrm{~min}$ incubation interval

\section{Imprecision}

Table 2 summarises the imprecision of the assays using 3 patient sera pools. Within-run imprecision studies were performed on two separate occasions by assaying 18 replicate samples with the poorest performance shown for each level. Coefficients of variation ranged from 0.50 to $0.64 \%$ for $\mathrm{Na}^{+}$and 0.70 to $1.67 \%$ for $\mathrm{K}^{+}$. Between-run studies using the same samples were performed over 21 runs on 11 working days, and coefficients of variation ranged from 0.57 to $0.83 \%$ for $\mathrm{Na}^{+}$ and 0.88 to $2.59 \%$ for $\mathrm{K}^{+}$. The data obtained were considered to be very good with the exception of the lowest $\mathrm{K}^{+}$concentration where the performance was satisfactory.

Tab. 2 Assay precision for 3 patient sera pools using BM/Hitachi enzymatic $\mathrm{Na}^{+}$and $\mathrm{K}^{+}$reagents with manual enzymatic techniques.

\begin{tabular}{|c|c|c|c|c|c|c|}
\hline & \multicolumn{3}{|c|}{$\mathrm{Na}^{+}(\mathrm{mmol} / \mathrm{l})$} & \multicolumn{3}{|c|}{$\mathrm{K}^{+}(\mathrm{mmol} / \mathrm{l})$} \\
\hline & Low & Mid & High & Low & Mid & High \\
\hline $\begin{array}{l}\text { Flame } \\
\text { emission } \\
\text { photometry }\end{array}$ & 126.9 & 143.6 & 157.5 & 2.48 & 4.23 & 6.64 \\
\hline
\end{tabular}

Within-run $(n=18)$ imprecision

$\begin{array}{lrrrlll}\text { Mean } & 125.3 & 142.6 & 155.8 & 2.52 & 4.40 & 6.67 \\ \text { SD } & 0.62 & 0.91 & 0.80 & 0.042 & 0.037 & 0.047 \\ \text { CV (\%) } & 0.50 & 0.64 & 0.52 & 1.67 & 0.84 & 0.70\end{array}$

Between-run $(n=21)$ imprecision

\begin{tabular}{lrrrlll} 
Mean & 126.2 & 143.0 & 156.7 & 2.56 & 4.40 & 6.70 \\
SD & 0.72 & 1.06 & 1.29 & 0.066 & 0.052 & 0.059 \\
CV (\%) & 0.57 & 0.74 & 0.83 & 2.59 & 1.18 & 0.88 \\
\hline
\end{tabular}


Electrolyte concentrations in serum were determined by routine flame photometry over 10 runs.

\section{Linearity}

Comparisons made by serial dilution of a high $\mathrm{Na}^{+} / \mathrm{K}^{+}$ serum pool with a low pool, demonstrate that the $\mathrm{Na}^{+}$ method is linear from at least 90 to $170 \mathrm{mmol} / \mathrm{l}$ (fig. 1). Over this range linear regression analysis gives $r^{2}>0.999$.

Similarly the enzymatic $\mathrm{K}^{+}$assay is linear as determined by serial serum dilution from at least 1.5 to $9 \mathrm{mmol} / \mathrm{l}$ (fig. 2) with regression analysis giving

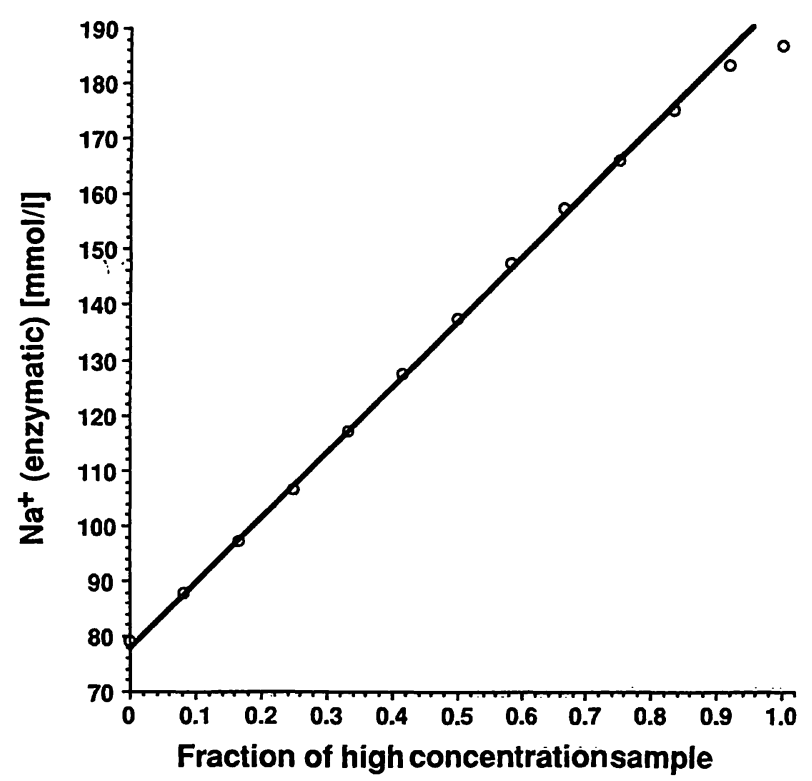

Fig. 1 Linearity of the manual enzymatic $\mathrm{Na}^{+}$assay. The linear range determined by serial dilution, was between at least 90 and $170 \mathrm{mmol} / \mathrm{l}$.

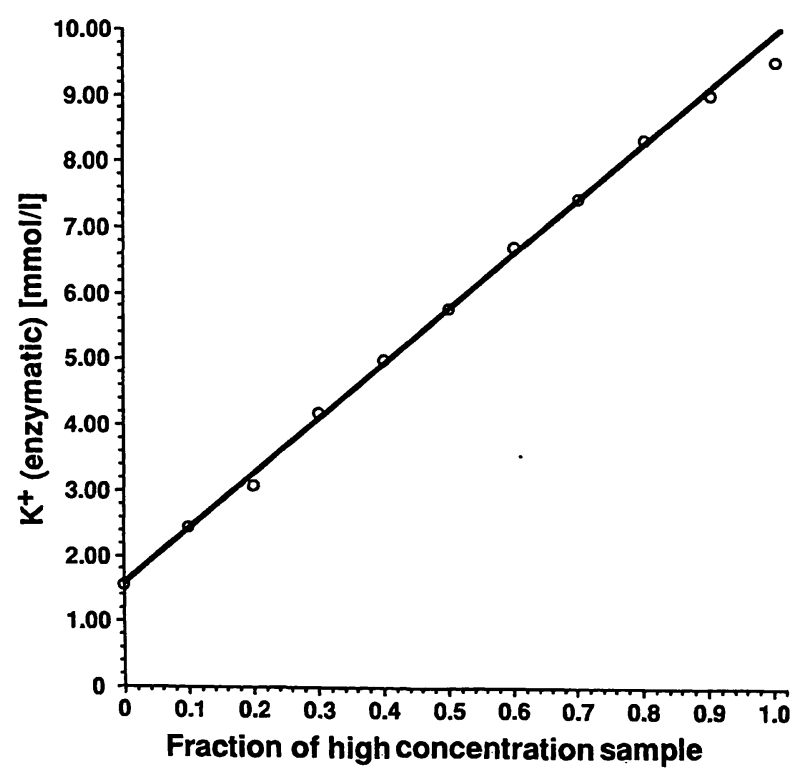

Fig. 2 Linearity of the manual enzymatic $\mathrm{K}^{+}$assay. The linear range determined by serial dilution was between at least 1.5 and $9 \mathrm{mmol} / \mathrm{l}$. $r^{2}>0.998$. Above this range the manual assay displayed a negative bias.

\section{Accuracy}

Table 3 shows the concentrations of $\mathrm{Na}^{+}$and $\mathrm{K}^{+}$determined by the manual enzymatic assays for the 3 SRM 909 sera compared to the definitive concentrations. For completeness, values obtained by routine flame photometry are also shown. It can be seen that the manual enzymatic techniques underestimate $\mathrm{Na}^{+}$by about $3 \mathrm{mmol} / \mathrm{l}$ at low concentrations and overestimates $\mathrm{K}^{+}$ by about $0.25 \mathrm{mmol} / \mathrm{l}$ at low to normal serum concentrations in these particular control sera.

\section{Interference}

Table 4 demonstrates the effect of haemolysis, triacylglycerols and ammonium ions on the $\mathrm{Na}^{+}$and $\mathrm{K}^{+}$assays. Due to the release of $\mathrm{K}^{+}$from red blood cells, haemolysis was not tested in the enzymatic $\mathrm{K}^{+}$asșays. There is an observable interference in the $\mathrm{Na}^{+}$assay when the sample concentration of haemoglobin is above $5 \mathrm{~g} / \mathrm{l}$, or lipaemia levels are above $2.5 \mathrm{~g} / \mathrm{l}$ of added Intralipid. In the $\mathrm{K}^{+}$assay lipaemia levels above $2.5 \mathrm{~g} / \mathrm{l}$ of added Intralipid cause interference in the enzymatic assay. From Table 5 it can be seen that bilirubin concentrations above $240 \mu \mathrm{mol} / 1$ appear to lower the measured $\mathrm{K}^{+}$. For every $100 \mu \mathrm{mol} / \mathrm{l}$ bilirubin the apparent serum potassium decreases approximately $0.1 \mathrm{mmol} / \mathrm{l}$. It appears that $\mathrm{Mn}^{++}$catalyses an increase in absorbance of a bilirubin product near the measuring wavelength which then interferes spectrally. The net result is an apparently reduced absorbance decrease at $360 \mathrm{~nm}$ and hence a lower measured potassium. It is possible to correct totally for bilirubin effects on the $\mathrm{K}^{+}$assay by the use of a reagent and sample blank (see Appendix and tab. 5).

In the case of lipaemic specimens, as both the basal pool and the high lipid pool are diluted to the same extent with either a similar volume of water or Intralipid respectively, it would be expected that there should be no change in either $\mathrm{Na}^{+}$or $\mathrm{K}^{+}$concentration. This is borne out by flame photometric analysis, however above $2.5 \mathrm{~g} / \mathrm{l}$ Intralipid the enzymatic analyșes both demonstrate a decrease in apparent $\mathrm{Na}^{+}$or $\mathrm{K}^{+}$concentration.

None of the drugs tested (tab. 6) showed any evidence of affecting either the enzymatic $\mathrm{Na}^{+}$and $\mathrm{K}^{+}$assays by more than twice the normal method standard deviation, when used at 5 times the maximum expected therapeutic concentration, and were therefore considered to cause no clinically important interference. 
Tab. 3 Accuracy: Determination of $\left[\mathrm{Na}^{+}\right]$and $\left[\mathrm{K}^{+}\right]$by enzymatic and flame photometric techniques in 3 SRM 909 sera. Values were calculated over 5 runs and are compared to concentrations assigned by definitive methods.

\begin{tabular}{|c|c|c|c|c|c|c|}
\hline & \multicolumn{3}{|l|}{$\mathrm{Na}^{+}(\mathrm{mmol} / \mathrm{l})$} & \multicolumn{3}{|c|}{$\mathrm{K}^{+}(\mathrm{mmol} / \mathrm{l})$} \\
\hline & SRM 909a-2 & SRM 909 & SRM 909a-1 & SRM 909 & SRM 909a-1 & SRM 909a-2 \\
\hline Definitive value $(\mathrm{mmol} / \mathrm{l})$ & 126.5 & 134.1 & 148.5 & 3.52 & 3.66 & 6.21 \\
\hline $\begin{array}{l}\bar{x} \text { (Flame emission photometry) (mmol/l) } \\
\text { Total imprecision (given as SD) } \\
\text { Bias }\end{array}$ & $\begin{array}{c}126.4 \\
0.44 \\
-0.1\end{array}$ & $\begin{array}{c}135.0 \\
0.52 \\
0.9\end{array}$ & $\begin{array}{c}148.9 \\
0.48 \\
0.4\end{array}$ & $\begin{array}{l}3.56 \\
0.06 \\
0.04\end{array}$ & $\begin{array}{r}3.63 \\
0.06 \\
-0.03\end{array}$ & $\begin{array}{l}6.25 \\
0.04 \\
0.04\end{array}$ \\
\hline $\begin{array}{l}\bar{x}(\text { Enzymatic) (mmol/l) } \\
\text { Total imprecision (given as SD) } \\
\text { Bias }\end{array}$ & $\begin{array}{c}123.2 \\
0.88 \\
-3.3\end{array}$ & $\begin{array}{c}134.9 \\
0.78 \\
0.8\end{array}$ & $\begin{array}{c}149.9 \\
1.11 \\
1.4\end{array}$ & $\begin{array}{l}3.80 \\
0.12 \\
0.28\end{array}$ & $\begin{array}{l}3.86 \\
0.10 \\
0.20\end{array}$ & $\begin{array}{l}6.29 \\
0.15 \\
0.08\end{array}$ \\
\hline
\end{tabular}

Tab. 4 Interference: The effect of haemoglobin, triacylglycerols and ammonium ions on the manual enzymatic $\mathrm{Na}^{+}$and $\mathrm{K}^{+}$assays (mean of 4 determinations with no correction). Electrolyte results are in $\mathrm{mmol} / \mathrm{l}$.

\begin{tabular}{|c|c|c|c|c|c|c|c|c|c|}
\hline \multicolumn{3}{|c|}{ Haemoglobin } & \multicolumn{5}{|l|}{ Intralipid } & \multicolumn{2}{|l|}{$\mathrm{NH}_{4}^{+}$} \\
\hline $\begin{array}{l}\text { Haemo- } \\
\text { globin } \\
(\mathrm{g} / \mathrm{l})\end{array}$ & $\begin{array}{l}\mathrm{Na}^{+} \\
\text {Flame } \\
\text { emission } \\
\text { (mmol/l) }\end{array}$ & $\begin{array}{l}\mathrm{Na}^{+} \\
\text {(enzy- } \\
\text { matic) } \\
(\mathrm{mmol} / \mathrm{l})\end{array}$ & $\begin{array}{l}\text { Intra- } \\
\text { lipid } \\
(\mathrm{g} / \mathrm{l})\end{array}$ & $\begin{array}{l}\mathrm{Na}^{+} \\
\text {Flame } \\
\text { emission } \\
(\mathrm{mmol} / \mathrm{l})\end{array}$ & $\begin{array}{l}\mathrm{Na}^{+} \\
\text {(enzy- } \\
\text { matic) } \\
(\mathrm{mmol} / \mathrm{l})\end{array}$ & $\begin{array}{l}\mathrm{K}^{+} \\
\text {Flame } \\
\text { emission } \\
(\mathrm{mmol} / \mathrm{l})\end{array}$ & $\begin{array}{l}\mathrm{K}^{+} \\
\text {(enzy- } \\
\text { matic) } \\
(\mathrm{mmol} / \mathrm{l})\end{array}$ & $(\mu \mathrm{mol} / \mathrm{l})$ & $\begin{array}{l}\mathrm{K}^{+} \\
\text {(enzy- } \\
\text { matic) } \\
(\mathrm{mmol} / \mathrm{l})\end{array}$ \\
\hline Basal (0) & 134.2 & 134.5 & Basal (0) & 137.1 & 135.3 & 4.21 & 4.48 & Basal (215) & 5.65 \\
\hline 0.63 & 134.1 & 133.4 & 0.7 & 137.1 & 134.6 & 4.21 & 4.50 & 330 & 5.53 \\
\hline 1.25 & 134.1 & 133.8 & 1.3 & 137.3 & 134.0 & 4.22 & 4.46 & 460 & 5.62 \\
\hline 2.50 & 134.0 & 132.9 & 2.5 & 137.2 & 132.4 & 4.22 & 4.09 & 600 & 5.63 \\
\hline 5.00 & 134.5 & 132.7 & 5.0 & 137.0 & 129.9 & 4.23 & 2.85 & 720 & 5.61 \\
\hline 10.00 & 135.6 & 127.8 & 10.0 & 137.1 & 126.5 & - & - & 860 & 5.59 \\
\hline
\end{tabular}

Tab. 5 Interference of bilirubin (above $240 \mu \mathrm{mol} / \mathrm{l}$ ) on the measurement of $\mathrm{K}^{+}$by manual enzymatic techniques. The elimination of this interference by subtraction of sample and reagent blanks can be seen.
For completeness the corresponding manual and flame photometer $\mathrm{Na}^{+}$values are shown.

\begin{tabular}{|c|c|c|c|c|c|}
\hline $\begin{array}{l}\text { Bilirubin } \\
(\mu \mathrm{mol} / \mathrm{l})\end{array}$ & $\begin{array}{l}\mathrm{Na}^{+} \\
\text {Flame emission } \\
(\mathrm{mmol} / \mathrm{l})\end{array}$ & $\begin{array}{l}\mathrm{Na}^{+} \\
\text {(enzymatic) } \\
\text { (mmol/l) }\end{array}$ & $\begin{array}{l}\mathrm{K}^{+} \\
\text {Flame emission } \\
(\mathrm{mmol} / \mathrm{l})\end{array}$ & $\begin{array}{l}\mathrm{K}^{+} \\
\text {(enzymatic) } \\
(\mathrm{mmol} / \mathrm{l})\end{array}$ & $\begin{array}{l}\mathrm{K}^{+} \\
\text {(enzymatic) } \\
\text { (mmol/l) } \\
\text { with bilirubin } \\
\text { correction }\end{array}$ \\
\hline 8 & 141.0 & 139.8 & 4.33 & 4.56 & \\
\hline 20 & 141.2 & 140.6 & 4.33 & 4.43 & \\
\hline 40 & 141.3 & 140.2 & 4.31 & 4.49 & 4.40 \\
\hline 60 & 141.3 & 140.5 & 4.32 & 4.49 & 4.44 \\
\hline 120 & 141.2 & 140.4 & 4.31 & 4.41 & 4.48 \\
\hline 240 & 141.4 & 139.6 & 4.32 & 4.28 & 4.47 \\
\hline 440 & 141.4 & 140.2 & 4.34 & 4.13 & 4.49 \\
\hline 850 & 141.6 & 137.7 & 4.34 & 3.80 & 4.43 \\
\hline
\end{tabular}

\section{Method comparison}

Figures 3 and 4 show the results of single determinations of $\mathrm{Na}^{+}$for 100 patients and $\mathrm{K}^{+}$for 140 patients by the enzymatic procedure compared to flame photometry. The Passing-Bablok regression test (3) was applied to the data and both techniques demonstrate a small but statistically significant difference at a $95 \%$ confidence level.

\section{Discussion}

There are at present no manual spectrophotometric assays described for the determination of $\mathrm{Na}^{+}$and $\mathrm{K}^{+}$in sera. The recently available linear kinetic enzymatic assays can be modified for end-point determinations suitable for manual spectrophotometers if a stop reagent is employed. Dipotassium EDTA, present in molar excess, binds magnesium ions, which are essential for $\beta$-galac- 
tosidase activity, and stops the formation of o-nitrophenol in the $\mathrm{Na}^{+}$assay. Similarly SDS eliminates enzyme activity in the $\mathrm{K}^{+}$assay. Stop reagents also enable both larger sample numbers and more precise $\mathrm{Na}^{+}$and $\mathrm{K}^{+}$ estimations in sera. In addition sophisticated spectrophotometers fitted with a thermostat are not required for performing these measurements and multiple cuvette holders are also unnecessary. A batch size of up to 20 assays is easily achievable.

Several other factors are critical for achieving maximal precision in manual assays. Since the reactions are kinetic in nature, correct timing of the manual assays is

Tab. 6 Drugs tested for interference with the manual enzymatic $\mathrm{Na}^{+}$and $\mathrm{K}^{+}$reagents.

\begin{tabular}{|c|c|}
\hline Drug & $\begin{array}{l}\text { Concentration in the sample } \\
(\mathrm{mg} / \mathrm{l})\end{array}$ \\
\hline Acetylsalicylic acid & 500 \\
\hline Allopurinol: & 50 \\
\hline Amitriptyline & 10 \\
\hline Amoxycillin & 80 \\
\hline Ampicillin & 50 \\
\hline Atenolol & 13 \\
\hline Budesonide & 3 \\
\hline Bupivacaine & 25 \\
\hline Captopril & 8 \\
\hline Carbamazepine & 120 \\
\hline Ceftriaxone & 1500 \\
\hline Cephalexin & 360 \\
\hline Cephalothin & 1000 \\
\hline Dextropropoxyphene & 15 \\
\hline Diazepam & 20 \\
\hline Diclofenac & 25 \\
\hline Digoxin & 0.01 \\
\hline Diltiazem & 1 \\
\hline Dothiepin & 1 \\
\hline Enalapril & 1.5 \\
\hline Erythromycin & 200 \\
\hline Felodipine & 0.08 \\
\hline Ferrous sulphate & 4 \\
\hline Flucloxacillin & 200 \\
\hline Gentamicin & 120 \\
\hline Heparin & $8000 \mathrm{iU} / \mathrm{l}$ \\
\hline Hydrocortisone & 5 \\
\hline Indomethacin & 10 \\
\hline Lignocaine & 60 \\
\hline Metoclopramide & 8 \\
\hline Metronidazole & 10 \\
\hline Mianserin & 1 \\
\hline Nifedipine & 1 \\
\hline Norfloxacin & 53 \\
\hline Omeprazole & 25 \\
\hline Oxazepam & 25 \\
\hline Paracetamol & 200 \\
\hline Phenytoin & 100 \\
\hline Piroxicam & 50 \\
\hline Prazosin & 1 \\
\hline Prednisolone & 8 \\
\hline Prochlorperazine & 1 \\
\hline Quinine & 20 \\
\hline Ranitidine & 200 \\
\hline Trimethoprim & 180 \\
\hline Verapamil & 4 \\
\hline Warfarin & 100 \\
\hline
\end{tabular}

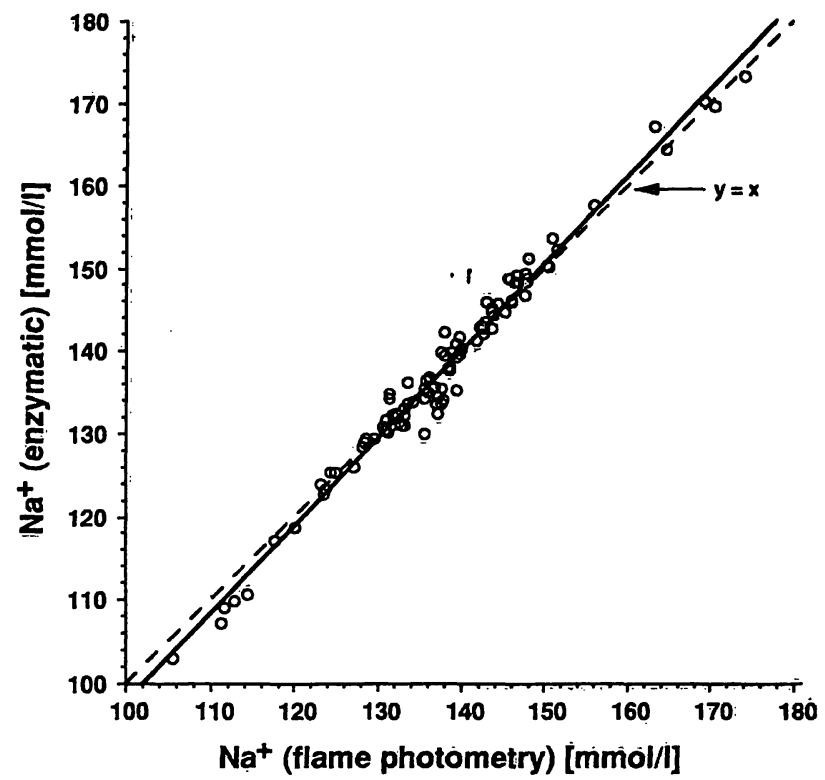

Fig. 3 Manually assayed enzymatic $\mathrm{Na}^{+}$patient comparisons in blood serum (single determinations) compared to flame photometry. The regression line obtained according to Passing \& Bablok analysis is $\mathrm{y}=-7.731+1.055 \mathrm{x} ; \mathrm{r}^{2}=0.980 ; \mathrm{S}_{\mathrm{y} . \mathrm{x}}$ (calculated from Standardised Principal Component analysis) $=1.26$ for $\mathrm{n}=100$.

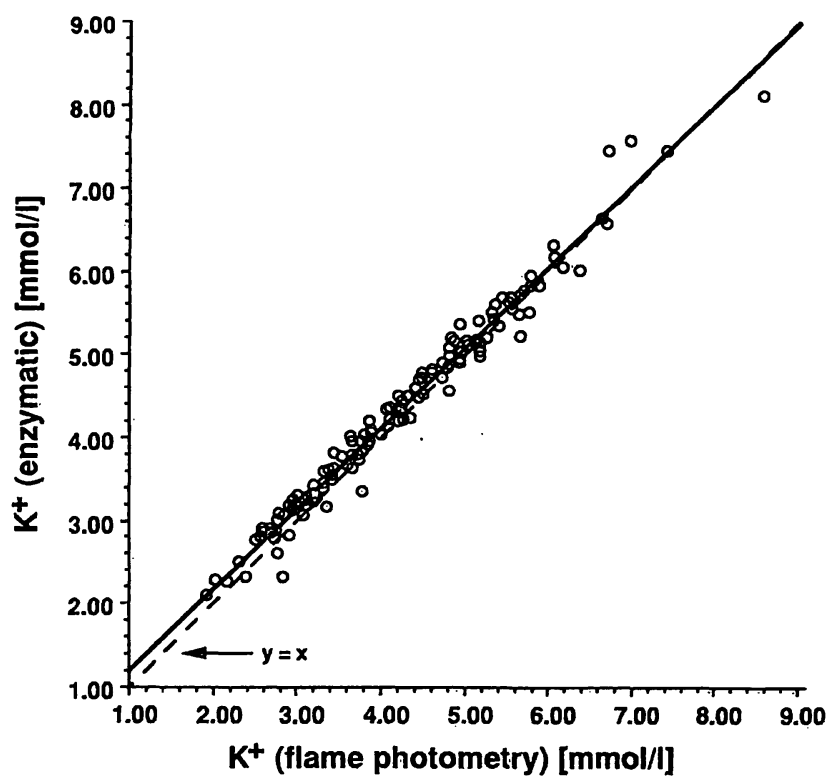

Fig. 4 Manually assayed enzymatic $\mathrm{K}^{+}$patient comparisons in blood serum (single determinations) compared to flame photometry. The regression line obtained according to Passing \& Bablok analysis is $y=0.240+0.970 x ; r^{2}=0.978 ; S_{y . x}$ (calculated from Standardised Principal Component analysis) $=0.13$ for $n=140$.

essential especially with regard to the addition of both the start and stop reagents. Precise pipetting of sample; main and stop reagents is equally important and we were not able to obtain satisfactory performance without the use of high quality positive displacement pipettes. The within and between run imprecision, linearity and accuracy data are almost equivalent to those obtained by mechanized analysers. This good overall performance is 
in large measure attributable to control of sources of analytical variation in the assays such as pipetting precision. The relatively large absorbance changes per $\mathrm{mmol} / \mathrm{l}$ of electrolyte during the measurement interval also contribute to overall assay performance. Although the $\mathrm{Na}^{+}$and $\mathrm{K}^{+}$patient comparison data do show a slight statistically significant difference when compared to flame photometry, this is not of clinical significance.

The Passing-Bablok regression equation for the $\mathrm{Na}^{+}$patient data in figure 3 shows that a sample with a concentration of $120 \mathrm{mmol} / \mathrm{l}$ by flame photometry would be expected to read only $1 \mathrm{mmol} / \mathrm{l}$ lower by the enzymatic technique and only $1 \mathrm{mmol} / \mathrm{l}$ higher at $160 \mathrm{mmol} / \mathrm{l}$. However although routine flame photometry accurately recovered the assigned electrolyte concentrations determined by the definitive methods for the three SRM-909 human serum samples, we observed that the $\mathrm{Na}^{+}$result for SRM-909a2 was over $3 \mathrm{mmol} / 1$ lower by the enzymatic method. This sample has a high $\mathrm{K}^{+}$concentration and the current Boehringer Mannheim reagent kit, unlike our original reagent formulation (1) may produce a small negative $\mathrm{Na}^{+}$bias at high $\mathrm{K}^{+}$concentrations as has been reported for a pooled serum control supplemented with $\mathrm{K}^{+}(7)$. Figure 3 (and 1. c. (7)) demonstrate however that bias is less in nonpooled patient serum samples and as such does not present a significant problem.

Interferences are more significant in the manual assays than for the automated kinetic procedures $(1,2)$. Addition of over $2.5 \mathrm{~g} / 1$ Intralipid to serum causes a decrease in apparent $\mathrm{Na}^{+}$or $\mathrm{K}^{+}$concentration. The reason is due to the combined high assay absorbances, which can excede $2.0 \mathrm{~A}$, resulting from $o$-nitrophenol and lipid in the $\mathrm{Na}^{+}$assay, or $\mathrm{NADH}$ and lipid in the $\mathrm{K}^{+}$assay. With lipaemic specimens in the manual $\mathrm{Na}^{+}$assay, the final absorbance reading can often exceed the absorbance linearity range of standard benchtop spectrophotometers. This is in part due to the longer assay times employed which result in greater $o$-nitrophenol concentrations because of the utilisation of endpoint rather than rate absorbance measurements. The absorbance linearity range of benchtop spectrophotometers is often lower than that found in automated analysers and this problem can further be aggravated by the use of $4 \mathrm{~mm}$ quartz cuvettes. The masking of the incident light helped to improve considerably spectrophotometer linearity to about $2.1 \mathrm{~A}$ in the instrument we employed. If the specimen cannot be clarified by ultracentrifugation, dilution with water before analysis remains an option for both electrolytes, or in the case of $\mathrm{Na}^{+}$, re-analysis of the sample at an incubation time of less than 8 minutes. On the other hand hyperbilirubinaemia causes a negative interference in the $\mathrm{K}^{+}$assay involving a $\mathrm{Mn}^{++}$catalysed increase in a bilirubin product with absorbance at $360 \mathrm{~nm}$. This effect however can be completely corrected by the inclusion of appropriate sample and reagent blanks in the assay (see Appendix).

We therefore conclude that $\mathrm{Na}^{+}$and $\mathrm{K}^{+}$may be reliably determined by enzymatic techniques on standard spectrophotometers and with minimal modification of the commercially available automated kit reagents. Excellent performance characteristics can be achieved providing attention is paid to the precise pipetting of sample and main reagent, timing of assays and an understanding of the interferences likely to be encountered. The manual methods should be especially useful in the small or medium-sized clinical laboratory, or as a back-up for mechanised instruments equipped with I. S. E. units.

\section{Acknowledgement}

We wish to thank Dr. V. Ehrhardt, Boehringer Mannheim GmbH, Mannheim, Germany for providing the enzymatic $\mathrm{Na}^{+}$and $\mathrm{K}^{+}$kits and also for valuable discussions, Mr. Michael Peake for useful suggestions and discussions, and Miss $J$. McCulloch for secretarial assistance.

\section{References}

1. Berry, M. N., Mazzachi, R. D., Pejakovic, M. \& Peake, M. J. (1988) Enzymatic determination of sodium in serum. Clin, Chem. 34, 2295-2298.

2. Berry, M. N., Mazzachi, R. D., Pejakovic, M. \& Peake, M. J. (1989) Enzymatic determination of potassium in serum. Clin. Chem. 35, 817-820.

3. Bablok, W., Passing, H., Bender, R. \& Schneider, B. (1988) A general regression procedure for method transformation. J. Clin. Chem. Clin. Biochem. 26, 783-790.

4. Passey, R. B., Carey, R. N., Clark, L. W., Hartmann, A. E., Kennedy, J. W., Kotsohi, M. L., Lee, H. T., Powers, D. M. (1989) Preliminary Evaluation of Clinical Chemistry Methods: Tentative Guidelines (EP10-T). National Committee for Clinical Laboratory Standards, Villanova, PA, USA.

5. Glick, M. R., Ryder, K. W. \& Jackson, S. A. (1986) Graphical comparisons of interferences in clinical chemistry instrumentation. Clin. Chem. 32, 470-475.
6. Powers, D. M., Boyd, J. C., Glick, M. R., Kotschi, M. L., Letellier, G., Miller, W. G., Nealon, D. A. \& Hartmann, A. E. (1986) Interference Testing in Clinical Chemistry: Proposed Guidelines (EP7-P). National Committee for Clinical Laboratory Standards, Villanova, PA, USA.

7. Steen, G., van Leeuwen, B., Langeslag, P., van der Reijden, J. J. (1994) Selectivity of enzymatic assays of sodium and potassium. Clin. Chem. 40, 671-672.

\author{
Michael N. Berry \\ Department of Biochemistry \\ and Chemical Pathology \\ Flinders Medical Centre \\ Bedford Park, South Australia, 5042 \\ Australia
}




\section{Appendix}

\section{Calculation of $\mathrm{Na}^{+}$concentration}

As detailed in the $\mathrm{Na}^{+}$assay Methods section above, obtain the initial absorbance readings $\left(A_{i}\right)$ at $405 \mathrm{~nm}$ for the two calibrators, samples or quality controls. Following incubation with the R2 and addition of EDTA stop reagent, take a final reading $\left(A_{f}\right)$ for each assay tube. In table 7 typical absorbance readings for the calibrators and a representative patient sample are shown.

Correct the absorbance readings $A_{f}$ for assay dilution to obtain:

$$
A_{c}=A_{f}\left(\frac{\text { Final volume of cuvette contents }}{\text { Sample volume }+R 1 \text { volume }}\right)
$$

This correction is particularly important when there is spurious absorbance caused by a component not present in aqueous standards (e.g. triacylglycerols) that may vary significantly between serum samples.

The difference between the corrected $\left(A_{c}\right)$ and initial $\left(A_{i}\right)$ absorbances yields the $\Delta A_{N}$ for each calibrator and specimen. To determine the $\left[\mathrm{Na}^{+}\right]$either plot a curve of $\Delta \mathrm{A}_{\mathrm{N}}$ versus $\left[\mathrm{Na}^{+}\right]$or alternatively calculate the result from the standard linear equation $\mathrm{y}=\mathrm{mx}+\mathrm{b}$.

Where $y=\Delta A_{N}, m=$ gradient of the curve, and $b=$ absorbance intercept for $\left[\mathrm{Na}^{+}\right]$of $0 \mathrm{mmol} / \mathrm{l}$.

Thus $\mathrm{m}=\left(\frac{\Delta \mathrm{A}_{\text {High Calibrator }}-\Delta \mathrm{A}_{\text {Low Calibrator }}}{[\text { High Calibrator }]-[\text { Low Calibrator }]}\right)$

and from the example in table 7

$$
\mathrm{m}=\frac{1.627-1.287}{160-120}
$$

Thus $\mathrm{m}=8.5 \times 10^{-3}$.

As $m$ represents the absorbance change per $\mathrm{mmol} / \mathrm{l} \mathrm{Na}^{+}$, by simple proportion calculate $b$ from the equation:

$$
\mathrm{b}=\Delta \mathrm{A}_{\text {High Calibrator }}-\mathrm{m} \cdot[\text { High Calibrator }]
$$

From table 7

$$
b=1.627-\left(8.5 \times 10^{-3}\right)(160) .
$$

Therefore $b=0.267$.

Rearrangement of the linear equation then produces:

$$
\left[\mathrm{Na}^{+}\right]_{\mathrm{N}}=\frac{\Delta \mathrm{A}_{\mathrm{N}}-\mathrm{b}}{\mathrm{m}}
$$

or $131.9 \mathrm{mmol} / 1$ for this example $\left(\left[\mathrm{Na}^{+}\right]=131.0\right.$ $\mathrm{mmol} / \mathrm{l}$ by flame photometry).

\section{Calculation of $\mathrm{K}^{+}$concentration}

Adopt the same approach to that of the $\mathrm{Na}^{+}$assay for the calculation of $\left[\mathrm{K}^{+}\right]$.

Table 8 below shows typical absorbance values for calibrators and a sample $\left(\left[\mathrm{K}^{+}\right]=4.33 \mathrm{mmol} / 1\right.$ by flame photometry). In addition $\mathrm{m}, \mathrm{b}$ and $\left[\mathrm{K}^{+}\right]_{\mathrm{N}}$ are included in the table and are dêrived similarly as described for $\mathrm{Na}^{+}$. Note although the calculation is correct, the sample has a very elevated bilirubin concentration and correction for this interference is detailed below.

\section{Correction of $\mathrm{K}^{+}$concentration for bilirubin interference}

It is possible to correct for the effects of a high bilirubin concentration on the $\mathrm{K}^{+}$assay by the use of a reagent and sample blank (tab. 5). To achieve this use an extra tube for the reagent blank and an extra tube for each sample with a high bilirubin. Dispense water and samples and pre-incubate with the $\mathrm{R} 1$ reagent as normal. Take an initial absorbance reading $\left(\mathrm{A}_{\mathrm{i}}\right)$ and add $250 \mu \mathrm{l}$ SDS to the water blank and to one of each duplicate reaction mixture containing the sample with high bilirubin. Add the $\mathrm{R} 2$ reagent to all tubes including the blank tubes in the normal timed sequence. At the end of the incubation, however, remove the water and sample

\begin{tabular}{|c|c|c|c|c|c|}
\hline $\begin{array}{l}\text { Absorbance } \\
\text { quantity }\end{array}$ & Definition & Derivation & $\begin{array}{l}\text { Calibrator } 1 \\
{\left[\mathrm{Na}^{+}\right]} \\
120 \mathrm{mmol} / 1\end{array}$ & $\begin{array}{l}\text { Calibrator } 2 \\
{\left[\mathrm{Na}^{+}\right]} \\
160 \mathrm{mmol} / 1\end{array}$ & Sample \\
\hline $\mathbf{A}_{\mathbf{i}}$ & Initịal abśorbance reading & Observed & 0.028 & 0.029 & 0.060 \\
\hline$A_{f}$ & Final absorbance reading & Observed & 1.057 & 1.331 & 1.164 \\
\hline$A_{c}$ & $\begin{array}{l}\text { Corrected final absorbance } \\
\text { reading }\end{array}$ & $A_{f}\left(\frac{1275 \mu l}{1025 \mu l}\right)$ & 1.315 & 1.656 & 1.448 \\
\hline$\Delta A_{N}$ & $\begin{array}{l}\text { Absorbance difference for a } \\
\text { calibrator or sample of } \\
\text { concentration } \mathrm{N}\end{array}$ & $A_{c}-A_{i}$ & $\begin{array}{l}1.287 \\
\left(\Delta \mathrm{A}_{120}\right)\end{array}$ & $\begin{array}{l}1.627 \\
\left(\Delta A_{160}\right) \\
. i\end{array}$ & $\begin{array}{l}1.388 \\
\left(\Delta \mathrm{A}_{\mathrm{N}}\right)\end{array}$ \\
\hline
\end{tabular}

Tab. 7 Characteristic absorbance readings and calculation of $\left[\mathrm{Na}^{+}\right]$in blood serum. As calibrators are run in duplicate, average

the two $A_{i}$ and also two $A_{f}$ readings for each calibrator before using the $A_{i}$ and $A_{f}$ absorbance values in calculations. 
Tab. 8 Characteristic absorbance readings and calculation of $\left[\mathrm{K}^{+}\right]$in blood serum. In this case a sample and reagent blank have also been included to correct for bilirubin interference in the assay.

\begin{tabular}{|c|c|c|c|c|c|c|}
\hline Quantity & Derivation & $\begin{array}{l}\text { Calibrator } 1 \\
{\left[\mathrm{~K}^{+}\right]} \\
3.00 \mathrm{mmol} / \mathrm{h}\end{array}$ & $\begin{array}{l}\text { Calibrator } 2 \\
{\left[\mathrm{~K}^{+}\right]} \\
7.00 \mathrm{mmol} / \mathrm{l}\end{array}$ & Sample & $\begin{array}{l}\text { Reagent } \\
\left(\mathrm{H}_{2} \mathrm{O}\right) \text { blank }\end{array}$ & $\begin{array}{l}\text { Sample } \\
\text { blank }\end{array}$ \\
\hline $\mathbf{A}_{\mathbf{i}}$ & Observed & 1.641 & 1.644 & 1.810 & 1.644 & 1.809 \\
\hline$A_{r}$ & Obscrved & 0.972 & 0.677 & 1.043 & 1.307 & 1.481 \\
\hline$A_{c}$ & $A_{f}\left(\frac{1325 \mu l}{1025 \mu l}\right)$ & 1.256 & 0.875 & 1.348 & 1.690 & 1.914 \\
\hline$\Delta A_{N}$ & $A_{c}-A_{i}$ & $\begin{array}{l}-0.385 \\
\left(\Delta A_{3}\right)\end{array}$ & $\begin{array}{l}-0.769 \\
\left(\Delta A_{7}\right)\end{array}$ & $\begin{array}{l}-0.462 \\
\left(\Delta A_{N}\right)\end{array}$ & & \\
\hline$m$ & $\frac{-0.769-(-0.385)}{7-3}$ & \multicolumn{2}{|c|}{-0.096} & $\begin{array}{l}\text { (Calibration } \\
\text { only) }\end{array}$ & & \\
\hline$b$ & $-0.769-[7(-0.096)]$ & \multicolumn{2}{|c|}{-0.097} & $\begin{array}{l}\text { (Calibration } \\
\text { only) }\end{array}$ & & \\
\hline$[\mathrm{N}]$ & {$\left[\mathrm{K}^{+}\right]_{\mathrm{N}}=\frac{\Delta \mathrm{A}_{\mathrm{N}}-\mathrm{b}}{\mathrm{m}}$} & & & $\begin{array}{l}3.80 \text { (no } \\
\text { correction) }\end{array}$ & & \\
\hline
\end{tabular}

blank tubes from the water bath (at the specified intervals) with no further SDS addition.

The patient sample in table 8 has a bilirubin concentration of $480 \mu \mathrm{mol} / 1$. Sample and reagent blanks are required only when a sample with a very elevated bilirubin concentration is assayed for $\mathrm{K}^{+}$. Only 1 reagent blank per run is required. The additional data needed for the reagent and sample blanks is shown in the two right hand columns in table 8.

Determine the reagent blank absorbance difference $\left(A_{r}\right)$ from $A_{c}$ and $A_{i}$.

i.e.

$$
\begin{aligned}
\mathrm{A}_{\mathrm{r}} & =A_{c}-A_{i} \\
& =1.690-1.644=0.046
\end{aligned}
$$

Determine the sample blank absorbance difference $\left(A_{s}\right)$ from $A_{c}$ and $A_{i}$

i.e.

$$
\begin{aligned}
\mathrm{A}_{\mathrm{s}} & =\mathrm{A}_{\mathrm{c}}-\mathrm{A}_{\mathrm{i}} \\
& =1.914-1.809=0.105
\end{aligned}
$$

Therefore the corrected $\Delta \mathrm{A}_{\mathrm{NC}}$ for the samples is:

$$
\begin{aligned}
\Delta \mathrm{A}_{\mathrm{NC}} & =\Delta \mathrm{A}_{\mathrm{N}}-\left(\mathrm{A}_{\mathrm{s}}-\mathrm{A}_{\mathrm{r}}\right) \\
& =-0.462-(0.105-0.046) \\
& =-0.521
\end{aligned}
$$

Substitute this value for $\Delta A_{N}$ in table 8 to recalculate $\left[\mathrm{K}^{+}\right]_{\mathrm{N}}$ :

$$
\left[\mathrm{K}^{+}\right]_{\mathrm{N}}=\frac{-0.521-(-0.097)}{-0.096}=4.42 \mathrm{mmol} / \mathrm{l}
$$

Thus it can be seen that $\left[\mathrm{K}^{+}\right]$is almost identical to the flame photometer result of $4.33 \mathrm{mmol} / \mathrm{l}$, however without correction $\left[\mathrm{K}^{+}\right]$is underestimated by over 0.5 $\mathrm{mmol} / \mathrm{l}$. 
